\title{
The rise and nature of Feminist Spirituality
}

\author{
Pieter G R de Villiers \\ Rhodes University
}

\begin{abstract}
This article discusses the growth and nature of Feminist Spirituality as a phenomenon in its own right and in juxtaposition to Feminist Theology. After attempting a definition of Feminist Spirituality, its links with doctrine are investigated and it is then placed within the framework of Contextual Theologies. As such, attention is drawn to seminal characteristics of Feminist Spirituality, namely its analytical approach, its rejection of a privatised spirituality and its emphasis on receiving as a form of spirituality.
\end{abstract}

\section{THE GROWTH OF FEMINIST SPIRITUALITY}

Feminist Spirituality, although a relatively recent development coinciding with the growing interest in spirituality during the last decades of the twentieth century, is by now an established movement. Already at an early stage of this period feminist thinkers actively reflected on a spirituality for women, convinced that to theologize about women's issues, about socio-political engagement and structures violating womanhood, not only assumes and reflects a particular spirituality, but also demands developing a spirituality for women and about women. The initial discussions soon led to formal courses on feminist spirituality being instituted at places of learning - mostly in the United States early in the eighties (Cady et al 1986:2; cf also Schneiders 1990:19; Pryor 1989). "Feminist spirituality groups are developing around the country, not only among radical feminists, but also among moderate feminists who recognize a need to cultivate their own spiritual gardens in a radically new way. So important is the emergence of feminist spirituality that it can be characterized as a major feminist development of the 1980s" (Cady et al 1986:2). 


\section{A DEFINITION}

As with any popular development, the understanding of spirituality is complicated by numerous participants who carry new baggage, assumptions and contents into the ongoing debate. As a result spirituality in general, and Feminist Spirituality in particular, can be understood in many ways (cf Cady et al 1986:79; Jantzen 1995:346). An overview of the history of the term is ample proof of dramatic shifts in its understanding. Before embarking on this exercise, it is necessary to point out that one should distinguish between spirituality as a movement and Spirituality as the academic study of a discipline that focuses on spirituality. In this essay, both are discussed. Feminist Spirituality is part of Spirituality as a discipline, but it should also be understood against a long history and against developments that are not necessarily studied academically.

\subsection{The initial period}

Feminist Spirituality obtains its profile against earlier forms of spiritual experience. The early history of Christianity does not distinguish between theology and spirituality, or between experiencing faith on the one hand and the academic study of theology on the other hand. In its earlier forms theology and spirituality were mutually determinative: theology would reflect on Christian experience, which reflection would, in turn, further spirituality (Schneiders 1990:25).

After the patristic period spirituality focussed on the interior life. It was characterized by asceticism, monasticism, withdrawal, and the privatizing and individualizing of religious experience, reaching its full expression in the exceptional phenomenon of monasticism in the fourth century (see McGinn 1992:131). Women also pursued this interior life in their quest for spirituality, participating so strongly in the monastic life in this period. Rosemary Radford Ruether (1981:153) points out that the Egyptian deserts were filled with large and active female communities. In fact, women played a leading role in the quest for the interior life. One such prominent woman leader was Macrina, who was regarded by the famous Gregory of Nyssa as the primary source of his own spiritual development and who was often seen as the first source of the Basilian Rule. In one sense this experience enhanced the status of women. Asceticism redeemed them from their subordinate position and female condition and provided them with the 
opportunity to become equivalent to the male. Ruether (1982:152) remarked that what seems, in hindsight, a rather oppressive asceticism, especially in its anti-sexual orientation, in fact represented an unique opportunity to women to acquire freedom from male and ecclesiastical domination, to study and to develop an own spirituality without being burdened with the traditional female roles of housekeeping and childbearing.

The oppressiveness of this spirituality is to be found in the fact that it had a distinct male character (cf Jantzen 1995:43-58; Ruether 1982:140). The Church Fathers can seldom eschew the tendency to speak about women as having a lesser capacity for virtue. The female "nature" is described as peculiarly prone to the vices of pettiness, sensuality, materialism, and maliciousness. The virtues of the mind, such as chastity, patience, wisdom, temperance, fortitude, and justice are equated with masculinity. Consequently, when a woman rejects marriage and procreation and aspires to the contemplative life, she is spoken of as having transcended her bodily and female nature. This accounts for the peculiar habit in patristic and medieval spirituality of referring to the female ascetic as if she had ceased to be a female. By rejecting the flesh, the female has become "manly" (Ruether 1982:150). This is confirmed by developments in doctrine that simultaneously enhanced and restricted the female condition. Mariology and the female image of the church especially were designed as spiritual images, but the way in which this was done in fact increased the negative perception of female sexuality and of physical motherhood (Ruether 1982:160-161).

This first phase of an individualistic interiorised spirituality continued throughout the Middle Ages. Spirituality was seen as closely connected with control of sexuality, food, clothing and, in the case of women, submission to the church and men. Major changes set in from the seventeenth century, which in the following two centuries, led to the academic study of Spirituality as the perfection of the Christian life, as a field separate from theology (Schneiders 1990:24-26). Spirituality was regarded as a legitimate, necessary complement to dogmatic or systematic theologies and taught as part of moral theology (see Schneiders 1990:26; cf also Hall 1990:202). Some consider this as a negative development on account of its division between theology and spirituality (cf Smit 1989a:83-94; Galilea 1988:3-7). 


\title{
2.2 A broader definition
}

Recently significant shifts have taken place in how spirituality is understood. It began to be seen more brpadly as faith experienced, and is especially linked to, amongst others, prayer, liturgy (cf Senn 1986:20-26; Minke 1989:31-36), the study of or reflection on Scriptures and a practical lifestyle. Spirituality in this sense has to do with the human, inner experience of God, of a transcendent dimension (see Cady et al 1986:2-3; cf also Roten 1994:102-129). This experience is either the focus in the study of Spirituality or, alternatively, becomes the driving force behind theologizing or programmes of action.

\subsection{Postmodern spiritualities}

In its most recent forms, spirituality has increasingly been characterized as multifaceted. In fact, the scenario has become so confusing that a clear understanding of what it is all about is no longer possible. A recent comment illustrates the extent and nature of these dramatic changes:

\begin{abstract}
"Spirituality" may indicate stoic attitudes, occult phenomena, the practice of so-called mind control, yoga discipline, escapist fantasies, interior journeys, an appreciation of Eastern religions, multifarious pietistic exercises, superstitious imaginations, intensive journals, cults, monastic rigors, mortification of the flesh, wilderness sojourns, political resistance, contemplation, abstinence, hospitality, a vocation of poverty, nonviolence, silence, the efforts of prayer, obedience, generosity, exhibiting stigmata, entering solitude, or, I suppose, among these and many other things, squatting on top of a pillar.
\end{abstract}

(Roten 1994:104).

A distinguishing feature of these new developments is that the cacophony of voices is given extensive theoretical attention and in some cases even legitimization. Roten (1994:104), for example, remarks that: "The surge of contemporary spirituality is multi-faceted and all-pervasive ... It has become a proliferation term operating with a clutter definition, good for ambivalent use ..." and, then adds, “... alas, sometimes for poignant ridicule of true spirituality." Perhaps the most significant aspect of this devel- 
opment has been the interdisciplinary approach to Spirituality, the broadening of Spirituality to include aesthetic experiences in culture and arts, and its secularization.

There are some mundane reasons for the growing awareness and development of many spiritualities. The rationalistic nature of established theology and the growth of psychology are widely recognized as contributing factors. Another is the openness to various and divergent forms of spirituality cultivated within the discipline itself (cf McGinn et al 1988; Maas \& O’Donnell 1990:11-21; Hanson 1990; Amirtham \& Pryor 1989). Recent developments are, however, inextricably linked in a more theoretical manner with the postmodern mind that questions uniformity and metaphysical thinking, whilst leaning to what Roten (1994:102) calls the "philosophical and spiritual irenism at all levels of the construction of human and non-human reality." Because of this irenism, coupled with a genuine curiosity about the "other" and the "different", the many forms of spirituality are being taken seriously. The irenism will not only ask about spiritualities, it will do so by taking them seriously, seeing them in terms of the situation and context in which they originated and letting them be presented preferably by representatives from within. This irenism in itself is an indication of an increasing intolerance of stereotyped thinking about the other. To some extent this reflects the relativistic attitude among some that there cannot be only one "correct" form of spirituality, whilst it certainly stimulates the debate about relativism in spirituality among others.

The result of these dynamics is that there are now many forms of Spirituality with many agendas, hidden ones as well. Feminist Spirituality has established itself quite firmly among these many forms of spirituality as a field in its own right, together with others like Black, Liberation and African Spirituality (see Schneiders 1990:20; cf also Roten 1994:104). Thus, not only confessional motifs, but political groupings develop spiritualities of their own. This in itself is quite striking, since it reflects the non-individual character of spirituality as well as a union between the two areas of spirituality and politics that were previously often considered contradictory or mutually exclusive (cf DiDomizio 1981:296). Not only are political issues now being drawn into the field, but political questions about all aspects and fields of spirituality are being posed. For instance: which concerns and positions are defended or entrenched by an existing 
spirituality? Who are excluded and who included? The power games that are operative in the various traditions are thus exposed.

The one butstanding feature of Feminist Spirituality that distinguishes it from previous forms of spirituality is that it deliberately and consciously seeks to address socio-political issues, clearly distancing itself from a privatised spirituality (cf Caprio 1982:135). One of the constant programmes is, firstly, the deconstructing of patriarchal and other oppressive structures. It argues extensively that women's spirituality should not fall into the trap of the earlier phases of spirituality that was essentially male in character. Broadly speaking one could argue that, in its second constructive phase, Feminist Spirituality seeks to establish and work out a symbolic universe that would reflect the female experience in female forms and manner.

\section{SPIRITUALITY AS DOCTRINE EXPERIENCED}

To understand the nature of Feminist Spirituality, one needs to take confessional dynamics into consideration. Doctrine generally contributed decisively to the many forms of spirituality in history. This is made abundantly clear by the existence of such traditions as Reformed, Catholic or Lutheran Spirituality (Bouyer 1963:vii; Hambrick-Stowe 1990: 96). At times doctrine is regarded as coercive and restrictive, working against spirituality (cf Schmiel 1981:167). This happens where doctrine is associated with cerebrality, intellectual dryness, sectarianism, or where doctrine has an idealist character. Mostly, however, the importance of doctrine is accepted and respected in the various spiritual traditions. In many respects doctrine represents, consciously or unconsciously, a way of life that has become so ingrained in a person that it becomes part of that person's deeper structures and determines the person's spirituality. That is why Spirituality is sometimes defined as "doctrine experienced".

Where doctrinal issues are celebrated it is because they can be enriching and contribute to a spiritual learning experience. It was noted above that an irenism lies behind many publications on different spiritualities. This irenism also has the function of fostering spirituality today through an understanding of the doctrinal roots of spiritual traditions (Hanson, 1990:11-12). In fact, an important part of postmodern spirituality is that it actively seeks to promote doctrine, especially as the division between reason and 
experience is considered illegitimate and tragic. In this regard Schneiders (1990:29) refers to Bechtle's discussion of the "post-Enlightenment lobotomizing of Western culture, that is the separation of thought from feeling, mind from heart." In a recent collection of essays from different doctrinal perspectives, Maas \& O'Donnell (1990:17) state: "It is a fallacy to think that we can be spiritual or have a meaningful relationship with God without being concerned about the specifics of doctrine. Our belief system shapes, in a definitive way, our relationship with God." And this is why Schneiders $(1990: 24,29)$ observes that Spirituality is in a general sense "the whole of the human search for self-transcendent integration and authenticity" and Christian Spirituality is a theological discipline, that is a discipline carried out "in the context of explicit reference to revelation and explicitly affirmed confessional commitment."

This insight is significant for Feminist Spirituality as perhaps the one form of Spirituality where the negative and positive influences of doctrine are most evident. In fact, doctrine gives rise to specific forms of spirituality that are developed for and by women. Because of the immense influence of doctrinal issues on feminist themes, it makes sense, for example, to distinguish between feminine (or women's) and Feminist Spirituality. Feminist Spirituality consciously excludes certain doctrinal positions, even though it is not a confessionally determined movement. This relates most of all to doctrine on Scripture. Where Scriptural passages about women, their role in marriage, the family and the church are regarded as prescriptive and still valid for today, quite a different form of women's spirituality would develop than where a different hermeneutical process is operative. In some charismatic and fundamentalist groupings with their more conservative and fundamentalist doctrine on Scripture, a distinct form of spirituality with catchy phrases like "total woman" is developed. Even though equality of men and women may be taught, male leadership and traditional women's roles are retained and seen as the ideal for true feminine spirituality (Caprio 1982:35-36).

For Feminist Spirituality, where some of the more radical voices call for a replacement of Scriptures by new sacred texts, a "total woman" spirituality is unacceptable on doctrinal grounds. These scholars call for the ordination of women, the abolition of sexist language in liturgy and God-language, as well as new leadership structures in the church, in order for women to attain full spiritual growth. The doctrine that 
undergirds this position is quite different: Scripture is interpreted with focus on its time bound character and is seen as a document for its time without prescriptive value. But even more than this, ideological power grips within and on Biblical texts are unmasked and deconstructed. The spirituality of women in the Pastoral Epistles, for example, is seen as a result of the type of society in which Paul lived and proclaimed the gospel. Submission, propriety, moderation and housekeeping as spiritual values reflect more of society than of the gospel. Much is made of the equality between gender groups among first Christians and of how this insight was lost in the course of the history of the early and later church (Schüssler Fiorenza 1983:394-417; Schottroff 1983:418-427).

Feminist Spirituality is keenly aware that the theologian's own social position determines the nature of spirituality. That is why it requires that patriarchal structures within which theologians live and think, should be questioned and debated. A recent remark by Jantzen (1995:17) illustrates this: "And in biblical studies and theology there has been distinguished work demonstrating how intertwined are the notions of a patriarchal God and the oppression of women, and how the methods of biblical study and doctrinal formulation have rested on assumptions that arise out of and reinforce white male domination, not only of women, but also of other races and cultures and of the earth itself" (cf also Ruether 1983; Schüssler Fiorenza 1983). Men, it is argued, would then read the Bible in such a way that it reiterates spiritual values that are important in their own patriarchal societie.

Before some concluding remarks about Feminist Spirituality and doctrine can be made, attention must be given to its relationship with contextual theologies.

\section{FEMINIST SPIRITUALITY AND CONTEXTUAL THEOLO- GIES}

The upsurge of spirituality in recent years coincided with the emergence of Contextual Theologies as another significant development on the theological scene (cf De Villiers 1993). Feminist Spirituality as a discipline in its own right has clear connections with other Contextual Theologies as a new way of doing theology. Other Contextual Theologies are, for example, Black, Liberation, Minjung, Political Theology, Political Hermeneutics, Theology of the World and Theology of Revolution (cf Bammel 1984:63). 
Feminist Spirituality, together with Feminist Theology, regard themselves as part of these theologies. An understanding of Feminist Spirituality requires an insight in these theologies, because they share similar features and programmes.

\subsection{Transformation}

A key motif in Contextual Theologies and Feminist Spirituality is transformation. Feminist Spirituality does not want to assist women merely to experience their faith meaningfully, but aims in the first place to transform completely the experience of their faith. Contextual Theologians claim a unique and new place in history. As Gutierrez (1973:13) remarks: "(T)heology of liberation offers us not so much a new theme for reflection as a new way to do theology." This means that Contextual Theologies want to question traditional Westem theologies and the established churches because of their failure to transform the oppressive status quo. This new character of Contextual Theology is explained by Sobrino (1985:10) in terms of the history of modern thought. He referred to two phases in the Enlightenment: the first phase, associated with Kant, brought about the liberation from dogmatic authoritarianism. In this first phase theology was engaged in a hermeneutical enterprise, seeking to understand the meaning of faith in a situation in which this meaning had become obscured. No effective consideration was given to the role of theology in transforming reality. The second phase sought liberation from wretched conditions of the real world. According to Sobrino (1985:10; cf also Min 1989:5; Bammel 1984:10-68; De Villiers 1987; Bussmann 1985:142-145) this phase started with the work of Liberation Theologians in South America. In this theology, the liberating function of theological understanding does not consist in explaining or giving meaning to an existing reality or to faith as threatened by a particular situation, but in transforming a reality so that it may take on meaning and so that the lost or threatened meaning of faith may also be recovered.

This phase in theology is new to the extent that it consciously and deliberately wants to focus on praxis, another keyword in Contextual Theology and perhaps its most characteristic feature. This means that it is a theology in a context, related to and operating within societal structures. It is a theology that wishes to be transformative of a particular situation and context. Feminist Spirituality argues along the same lines in 
terms of the spirituality of women. True spirituality that is in line with Jesus and the Biblical message is against injustice and will not legitimize existing structures that relegate women to inequality, defining their role in terms of positions in the household or in patriarchal society, but will question these structures and work actively towards their transformation (cf Rayan 1992:24). Feminist Spirituality is part of this process when it questions the male understanding that often dominates spirituality. In its long term aim of developing a human spirituality, the challenge is to remove the prevalent, male orientated notions of spirituality by unmasking them in their coerciveness, pointing out their reductionist character in explaining human spirituality and replacing them with the necessary male and female images for a full, human life in the spirit. Feminist Spirituality does not only want to speak about the meaning of faith in overcoming anxiety, doubt, tension and unhappiness. It also wants to discover the root causes of this anxiety which lie on a social level, and to remove them.

\subsection{Analysis}

Contextual Theologies oppose oppressive structures by means of a typical approach of analysing, evaluating and acting. They argue that who people are and how they act, are decisively determined by their place in society. Theology needs to assist the underdogs, the powerless who are being exploited and oppressed by those in power. It is decisive to determine the location of the power struggle by social analysis. In the case of Feminist Spirituality the understanding of women is constructed by investigating the place allotted to them in society, how it affects their personhood and experiences of God. In this process, the analytical phase acquires exceptional importance, in most cases replacing Scripture as point of departure in theologizing. Scripture, if relevant, would only become a partner in a second phase, once the analysis has been completed. This analysis does not merely look at events in reality. It is a controlled investigation, with not only a social character, but with social models.

In a recent reflection on Spirituality in an Asian context by a group of Contextual Theologians (Fabella et al 1992:7-8) many of the contributions depended heavily on such observations of social issues. Because of this link between spirituality and society, the publication contains contributions on spirituality in the Korean Minjung tradition, while it 
investigates quests for spirituality in Indonesia, India, the Philippines, Hong Kong and Sri Lanka. In all the contributions repeated references to political and social structures are found. Feminist Spirituality is clearly a burning issue in this work. In the introduction, for example, the editors analyse the Asian situation (see Fabella et al 1992:7-8; cf also Rayan 1992:11-30) remarking specifically that in the male oriented and dominated Asian societies, women have been severely disadvantaged. "(T)heir education is neglected, their opportunities limited, their role in society restricted." Widespread prostitution in these countries degrades and exploits women further. The meeting of twenty men and twenty women from all over Asia debated this situation, rejecting the notion that sexuality is the antithesis of spirituality. "The challenge was posed: What has liberation spirituality to say and to do about sexuality in the Asian setting?" (Fabella et al 1992:78). The answer is then sought in the reappropriation and reintegration of the Bible from the perspective of "women in struggle, and to give new meaning and courage to women in the midst of their violence-filled lives. A critique of traditional, patriarchal images of God and of Christology and a search for new, more liberative, compassionate, healing, and nurturing images assume significance" (Fabella et al 1992:71).

In the same publication the loaded notion of "contemplation" is linked with "analysis" in a very interesting way. The Indian Preparatory Group (Fabella et al 1992: 71) speaks of contemplation of nature and history. Contemplating nature reflects a concern for the environment and respect for the earth as "the basic sacrament of God". To contemplate history is to discern the signs of what God is doing and to our collaboration therein. "Contemplation may, in fact must, deepen into probing and analysis of social reality with a view to a finer response" (Fabella et al 1992:77). Analysis takes on a spiritual character here, becoming almost a Godlike perspective on reality in its brokenness, its woundedness and its subjection to evil, with a clear flow towards acting in reality, making a difference by liberating it from evil as participating in God's work.

One only needs to read Thomas Merton's Seeds of contemplation (1961) to understand the shifts that are taking place here. Merton also affirms life. Contemplation is "spontaneous awe at the sacredness of life, of being. It is gratitude for life, for awareness and for being." But then contemplation moves deeper to the realization that life and being proceed from an "invisible, transcendent and infinitely abundant Source." That is 
why he can speak of contemplation as "a vivid awareness of infinite Being at the roots of our own limited being." And, if one does move on to speak of our response, it happens "in the depth of our own being" so that contemplation becomes a "deep resonance in the inmost center of our spirit in which our very life loses its separate voice and re-sounds with the majesty and the mercy of the Hidden and Living One" (Merton 1961:1-3). The focus of the contemplation on the self, the inwardness, the soul, is replaced by the horizontal reality, by the visible in the analytical phase of Feminist Theology. And it is a reality that takes on divine, sacramental-like features.

The element of analysing is especially important in the case of Feminist Spirituality. It distinguishes proponents of this spirituality from others. If theologizing with such an analysis as point of departure, it is unavoidable that quite different results are reached than those of a more Scripture orientated hermeneutics. In the latter case Scripture functions as a given, as a rule for interpretation, rather than as already an interpretation which needs to be analysed as a social construct that creates meaning. This position also raises the question about the exact nature of Scripture and analysis. To what extent is analysis linked with Scripture as the Word of God? How and according to what rules does the enlightened, spiritual mind, nurtured by Scripture, at some stage (because it is Christians that analyse) reflect on society in such a way that it can deviate so decisively from what others regard as seminal features of Scripture? For example, women who came to faith through Scripture, discover in Scripture itself oppressive and exploitative features which they then reject. What are the determinative dynamics in this process? Can analysis retain such an authoritative position? What higher insights determine analysis above others and why?

\subsection{Spirituality and Politics}

A quotation from a well-known representative of Liberation Theology will illustrate the roots, nature and function of Contextual Theologies generally, and, by implication, Feminist Spirituality specifically as a new paradigm of theologizing that came to the fore since the seventies: 
As early as 1969 , Hans Urs von Balthasar was reinterpreting political theology, then in its infancy, as a rediscovery of "biblical spirituality", and exhorting his readers: "Let us not clip the wings of a generation that has had the sensibility to discover the unacceptability of a divorce between theology and spirituality, contemplation and action, church and world." Karl Rahner, alluding to the example of St. Thomas, pleaded for a transcendence of "that frightful division, in later theology, between theology and the spiritual life." Political theologian, Johannes B. Metz has spoken of a "mystique and policy of discipleship." These citations are merely indicative, of course, but they demonstrate an awareness of the need for an integration of spirituality into theology as one of its essential dimensions.

(Sobrino 1985:48)

What is happening here, is a reintegration of theology and spirituality, whereby theology or reflection on God is inextricably linked with spirituality, the practical life, or action in the world. Such an integrated approach will be deeply transformative of reality, of existing structures (cf Rayan 1992:25-26).

One of the popular accusations against these Contextual Theologies is that they are thinly disguised political programmes. Proponents respond to this by emphasizing the spirituality that is involved. McGovern (1989:83) puts it as follows:

Controversy over issues about Marxism, social analysis, and political readings of scripture has created a distorted image of liberation theology. In terms of quantity, especially if one examines liberation theology in the 1980's, writings about liberation spirituality far outweighs works in all the areas that arouse debate. I would clearly designate spirituality as the dominant theme of contemporary liberation theology. This spirituality involves both a call to follow Jesus in working for and with the poor, but also profound reflection on what all Christians can learn about God from the poor (my italics).

Contextual Theologians, therefore, are making important contributions to the discipline of Spirituality, claiming that ultimately their own theologizing is driven by and focuses on spirituality (cf Boff \& Boff 1984:2, 25). This nurturing of Spirituality is not 
an apologetic stance, but represents the very essence of social engagement. Sobrino $(1985: 13,48,49)$ observes: "True, the theology of liberation has dealt more explicitly with the practice of liberation than with its spirituality." He explains it further: "It should be evident that, from the outset, this theology has professed an utopian and praxic mentality of partiality toward the poor, in virtue of its intended function in the liberation of poor majorities, its very raison d'être. But this has not been an exercise in reductionism, all allegations to the contrary notwithstanding." Quoting many examples of an implicit spirituality in theology of liberation, he finally states that spirituality is an integral dimension of the whole of theology.

\subsection{A rejection of an inner spirituality}

The inverse of the previous is that Contextual Theologians distance themselves from a form of spirituality that has an ascetic or private character. In doing so, they obviously think of the extreme forms of spirituality that characterize the history of Christianity which, at times, had the character of widespread hysteria. Historical precedents of such a distorted form of spirituality manifested in the seventeenth century, during the "golden age of spirituality", when the term was associated with the interior life of the Christian, but mostly in a negative sense (Schneiders 1990:20). In this distorted understanding spirituality referred to an exaggerated piety that was world-denying and self-serving. "Thus spirituality came to be associated with questionable enthusiasm or even heretical forms of spiritual practice (such as quietism)" (Schneiders 1990:20).

\subsubsection{Farewell to a devotional spirituality}

In Feminist Spirituality the criticism is more comprehensive than merely directed at the excesses. Even spirituality as "devotion, which places a proper emphasis on sobriety and human effort even in the life of the mystic" (Schneiders 1990:20) is under suspicion. Developing some thoughts of Gustavo Guitiérrez from his 1971 publication, Beber en su propio pozo, Sobrino (1985) refines the notion of spirituality by distancing himself from a "pure" spirituality focusing on a personal relationship with God that has nothing to do with the reality of everyday life. Active solidarity with the poor is what spirituality is all about, even if an experience of God is necessary for a genuine encounter with the poor. 
Similar feelings about the nature of spirituality were expressed by Indian Christians in the above mentioned publication on Asian Spirituality (Fabella et al 1992). This illustrates the decisive shift in the understanding of spirituality that has taken place from earlier forms of spirituality to that of the Contextual Theologians. "Spirituality has ... come to be looked upon as world-negating, non-historical, non-political, and hence as something private, subjective, and pacifying; it has to do with an important segment, but a segment of life, and is unrelated to the rest. This restrictive, reductionist, and dualist view of spirituality we reject." (Fabella et al 1992:76). To Feminist Spirituality this private understanding of spirituality smacks of neutrality, and leaves it wide open to misuse by anyone who claims to be working for a good cause. In this way a domineering husband, for instance, can continue with his dehumanizing gender attitudes and exploit his wife without feeling a discrepancy with his faith experiences. In stead of a private spirituality one needs a spirituality that is bound up with life and all that life involves:

... freedom and food, dignity and equality, community and the sharing of resources, creativity and celebration of the God of life and liberation ... It may be described as the Godwardness of life, the experience of seeing God in all things and all things in God; or, as a sustained search for meaning, depth, transcendence, and comradeship, overcoming mental and social inertia and determinisms in order to grow in freedom and to be able to relate to reality.

(Fabella et al 1992:76)

\subsubsection{Denigrating Spirituality as feminine}

The concern about privatized spirituality is even more serious in the case of Feminist Spirituality. This is the one tradition of spirituality where a privatizing spirituality would seriously threaten not only the wellbeing of women, but ultimately spirituality itself. Traditionally women were associated with subjectivity and emotion, while men were regarded by themselves as the objective, rational and therefore more legitimate thinkers. Thus spirituality, in a highly complicated manner, became associated in the minds of many, with an innocuous, feminine activity that takes a second place to theology (Jantzen 1995:344). Feminist Spirituality, rejecting this position, takes up a mission against such 
sexist thinking for the sake of spirituality itself. If such thinking goes unchallenged, it means that spirituality is degraded to an inferior position.

The dynamics of this criticism can be compared with criticism of a general attitude towards religion. One of the more serious threats to religion generally is the way in which it has been relegated to the private sphere. Religion, according to this position, has little to do with public life, and if it is at all relevant, it is only in order to provide an inner, private experience for removing some of the tensions, anxieties and inner turmoil that complicate decision making and affectivity in the public sphere.

This view of religion is rejected by arguing that religion has important societal implications. This was argued strongly by Feminist Theology. Similarly one can now argue that what one is spiritually, in one's interior life, has direct links to and consequences for public life. The struggle against a privatized spirituality is therefore a struggle for the very soul of religion itself.

\subsubsection{Spirituality outside of the struggle}

The implications of the above are clear: In the first instance Spirituality is claimed to be an integral part of the struggle against those who seek to discredit Feminist Theology as yet another activist movement. At the same time a type of spirituality which may stand in the way of the true liberation and spiritual growth of women is rejected. Such a type of spirituality ignores the need to act communally in order to restore women to their rightful place in public, societal structures. In other words, what is rejected is a spirituality that is directed only against symptoms of individual anguish and pain, without moving deeper to the underlying causes.

It is often argued that a true and effective relationship with God will promote a better world. Feminist Spirituality is an important movement to counter this naive position. The impatience with such an "inner spirituality" becomes rather compelling in a situation of severe oppression. Because the unequal position of women in many cultures still goes largely unrecognized and also because some forms of violence have become increasingly sophisticated, liberation from the oppressor has become a matter of urgency. The fascinating work of Foucault provides literature which sensitizes theologians to the reality in which we live and to the urgent nature of the struggle. He describes 
the increasingly sophisticated and highly complex nature of power relationships behind the Western prison system, despite the pretense of being more enlightened than in foregoing dark ages (see Foucault 1977). Because society is the playground for the worst crimes against women, it becomes the locus of the struggle.

Some problems connected with the nature and focus of Feminist Spirituality need to be overcome. There is, for instance, a need to discover more about the spirituality outside the struggle. The one who analyzes the structures has already had some inner, experiential encounter with God. Such an encounter lies behind the reflection on maleand femaleness in theologizing and in Feminist Spirituality. To a certain extent this "initial" or "independent" encounter takes place before and away from the struggle. It generates the struggle. It has to do with a spiritual rebirth. It is an understanding of who one is before God. It relates to a new perspective on reality, on creation, on humanity, on morality. One has to come to terms with this perspective by and in oneself. The encounter with God is part of faith. The struggle for women is either present in this faith from the beginning, or at some stage it becomes a part of it.

This spirituality not only represents a turning point towards the struggle. Spirituality goes beyond the struggle for the liberation of women. Even after having been completely liberated, women (and men) will always experience anguish and pain of some sort. This will not necessarily be related to their gender. The human condition of anxiety needs meditation and reflection in an ongoing encounter with God. To oppose the private nature of spirituality and link it only to social activism is a reductionist view (cf Jantzen 1995:344). Feminist Spirituality will have to reflect on its own nature and on the parameters within which it operates. At times, however, the nature of the struggle and the nature of religion demand reflection on the issue of "types of spirituality" that fall outside the ambit of Feminist Spirituality.

\subsection{Receiving as a form of spirituality}

One of the most important contributions of Contextual Theologies to the understanding of spirituality is to be found in another negative reaction, which has profound implications for Feminist Spirituality. Liberation Theologians, debating the nature of spirituality, asked whether a spirituality could exist outside of the struggle on behalf of the poor. 
Spirituality, they argued, involves both a call to follow Jesus in working for and with the poor, and also "profound reflection on what all Christians can learn about God from the poor" (McGovern 1989:83; my italics). In fact, this is a reason why faith lacked efficacy in the past.

In times gone by, the church was bound to the dominant classes, and it was through their mediation that the church reached out to the poor, to whom the dominant classes were giving assistance. The presence of the church was assistentialistic, paternalistic. The church came to the aid of the poor, it is true, but made no use of the resources of the poor in instituting a process of change.

(Boff \& Boff 1984:3 - my italics)

This is a fundamental insight.

The motif of the poor as a source of spiritual growth was perhaps best worked out by the Chilean theologian, Galilea, in his book on Contextual Spirituality. Writing about the experience of the poor as spirituality, Galilea $(1988: 133,137)$ notes that the poor are subjects of a spirituality that they communicate at the same time they receive the spirituality of the missionary church among them. They are not objects of the spirituality of the elite who opt for them. This is not because of any inherent and special personal qualities they may have, even though their faith within a situation of poverty may be inspiring and deeply spiritual. It is because they remind of gospel values such as solidarity, hospitality, vulnerability, mercy, care, that enrich those who experience and those who dispense. Also, sharing with the poor reveals who God really is - a God inextricably involved in suffering. In fact, we are evangelized by the poor because they help us grow spiritually. We become more contemplative, prayerful and reflective on who Jesus is as the one who sides with the poor.

It is this last phrase that represents the crossing over from Contextual Theology to Contextual Spirituality. Here one recognizes that the liberation of others is not a one way movement from the privileged to the oppressed. To become involved in the struggle is not simply to embark on a cause of liberating "them". Those who give, who support, 
who struggle, are at the same time those who receive, who are supported and who are allowed to become part of the struggle. It must be understood that pride and arrogance could motivate and characterize the pursuit of liberation. It must be understood that there is also sin and failure among the oppressed. Therefore those who become involved in the struggle need contemplation and prayer in order not only to fight unjust structures, but to do so in such a way that their own humanity as well as the frail humanity of the poor is preserved. Contemplation and prayer is needed to become as poor as the poor, female as the female, and in order to be sensitive to the human dignity that the oppressed battle to retain amidst their pain and anger.

Realizing that the struggle for human dignity can become just another search for glory and self-realization, all involved need to contemplate and reflect on who and where God is in terms of their struggle. Only then will they grow spiritually. The realities we analyse and wish to liberate, "are in fact words of God, ways in which God is disclosing God's heart and saying something to us" (Rayan 1992:23). This insight has a wonderful, liberating power. It simply means that to patronise is perhaps the most offensive attitude of those who reflect on or engage in Feminist Spirituality. Such an attitude denies women the inherent dignity that is their God-given right. The liberal, understanding and do-gooder men's club does in fact not really set out to liberate women. On the other hand, women must allow themselves to be taken seriously in open, honest, critical and sharp debate about how they see themselves and men. Feminist Spirituality is not about a patronising meekness and friendliness. It is about mercy, justice, compassion, care and other strong divine qualities that sometimes require the binding of the wounds, but sometimes also cutting out the rot and malignancy.

\section{CONCLUSION}

By way of conclusion, the above can well be illustrated by a recent debate between two well-known representatives of contextual theological approaches. In her report on her visit to Lima, where she met leaders from the Women's Ecumenical Round Table and the Catholic Talitha Kuma movement, Rosemary Radford Ruether referred to the distinction Gustav Gutiérrez (Peruvian liberation theologian and Catholic priest) made between feminist and liberation theology. According to Ruether, Gutiérrez regards feminism as 
foreign to Latin American thought and detracting the attention from the fundamental liberation of the poor. Ruether's was surprised that Gutierrez has never really taken the spirituality of the indigenous Indian tribes seriously. According to her this reflects an attempt to keep liberation theology within the confines of institutional Catholicism. She also points out how he ignores new fields, such as feminism, sexuality, reproduction, ecology, Protestant perspectives on religion and indigenous religions (National Catholic Reporter, as recorded in Inter Nos 28 3/98).

This debate illustrates not only how important the role of doctrine is in spirituality, but also how complicated it has become to write on Feminist Spirituality. Not only confessional doctrine and societal structures, but hermeneutical insights and theological positions contribute to or restrict forms of Feminist Spirituality. From the above remark of Ruether's, it is strange to see how a progressive political agenda (the liberation of the poor from oppressive structures) can be paired with a conservative ecclesiastic position (retention of a male ecclesiastical structures). Whilst the empowerment of the poor is pulled into the heart of theological reflection, the liberation of women, especially spiritually, is moved to the periphery. On the other hand, it is striking to see how Ruether focuses on coherence of thought and action. What is needed, is consistency in the liberation struggle. A feminist position with its sensitivity for oppression and bondage, is extended in a consistent way toward the liberation of other institutions and areas where women are unfree. It is ultimately a remarkable insight in the nature of Spirituality itself as a irenist movement that wants a renewal of theology beyond the traditional confines and wants to think inclusively about all areas of human oppression.

Feminist Spirituality represents a major development in modern theological thought. It reflects a totally new paradigm of theologizing that transcends an individualist, interior experience of faith, and that seeks to transform society. At the same time it struggles with many of the problems of traditional theology, that is, with the hermeneutical and doctrinal issues that determine how faith is experienced. It also seeks to overcome stagnation in traditional theologies by focusing on transformation, and, perhaps, by creating an awareness of the seminal role female spirituality has to play in healing a broken world. As in all human endeavours, there are major problems and obstacles regarding this new movement, but those require separate attention. That 
Feminist Spirituality contributed decisively to the spiritual healing and growth of women, and consequently of men too, is beyond question. Through its liberation of women and the dynamic, powerful process set in motion by women taking up their rightful positions in society with a deep inner strength, Feminist Spirituality is contributing to the spiritual healing of humanity as few other movements have done before.

Feminist Spirituality has taught us that spirituality is generated within and by the struggle. It is a spiritual experience to realize and acknowledge that women have indeed been exploited and to challenge the pious denials of this. It requires deep reflection on the character of God. Faith and the believing community have to come to terms with how inequality between sexes has been perpetrated over many centuries. The burden of history can become a heavy and suffocating one, causing much pain and threatening faith in the love of God. True spirituality will have to come to terms with this or develop where people come to terms with it. An even more difficult task is to become enpowered in order to counter the extremely powerful forces that resist changes to the status of women, to work towards a liberated time and world, to be strong enough for conflict if necessary. It can be extremely painful since it is often conflict with loved-ones within the family, with society and the believing community.

A strong inner encounter with God is required in order to overcome the battered syndrome. A profound inner reflection and meditation is demanded in order to develop a dignity that will counteract a self-deprecating attitude and cultivate an awareness of one's God-given value (Cady et al 1986:83). A special strength of inner contemplation is necessary in order to ponder the oppressors' condition and to break through their suffering under their own prejudices, assumptions, attitudes and actions in such a way that women and men will all grow spiritually. The condition of the oppressor, but also the nature of the process of restoration and healing, must be understood spiritually and conducted in a spiritually mature way.

For all of this the women's movement needs to reflect deeply on spirituality. The struggle is already spiritual when the pain of being enslaved is recognised and expressed in language, story and analysis. Speaking out about it, empowers. As such it transcends a privatized spirituality. Speaking out about it communally, empowers even more. 
A person frees herself from past hurts by recognizing it, by expressing that pain to herself and others, and by acting in whatever way is possible. Dorothee Sölle describes the affliction of certain factory workers and concentration camp inmates, suggesting that the worst kind of suffering is that which has no expression at all - 'the suffering that can find no language', she calls it. In the cosmos of connectedness toward which we are moving, groups and individuals will be able to acknowledge their own experience of pain and assume responsibility for the pain they have caused others.

(Cady et al 1986:88)

What a challenge to experience faith in such a way that it will reach out and empower even those who have no longer a story to tell, who have descended into the hell of having lost the ability to speak about their pain.

This spirituality is, however, not always so lachrymose. "Women's attempts to break through the culture of silence and to transform their pain into political power are a deeply spiritual experience" (Fabella et al 1992:71). Discovering a symbolic world and metaphors that express womanhood spiritually and the victory over the bondage and imperialism of maleness brings joy and a time for praise and worship. Finally, what greater spirituality can there be, once one has transformed pain into political power, than to remain a servant, to remain wakeful of the corruptive nature of power, to be eternally on the side of the poor and the powerless - even as a powerful figure.

\section{Literatuurverwysings}

Amirtham, S \& Pryor, R (eds) 1989. The invitation to the feast of life: Resources for spiritual formation in theological education. World Council of Churches. Programme on Theological Education.

Astell, A W 1994. Feminism, deconstructing hierarchies and Marian Coronation, in Astell, A W, Divine representations: Postmodernism and spirituality, 163-176. New York: Paulist.

Bammel, E 1984. The revolution theory from Reimans to Brandon, in Bammel, E \& Moule, C F D (eds), Jesus and the politics of his day, 10-68. Cambridge: Cambridge University Press. 
Barnard, G W 1994. Transformations and transformers: Spirituality and the academic study of mysticism. Journal of Consciousness Studies 1.

Boff, L \& Boff, C 1984. Salvation and liberation: In search of a balance between faith and politics. Maryknoll, NY: Orbis.

Bouyer, L 1963. The spirituality of the New Testament and the Fathers. New York: Seabury.

Bussmann, C 1985. Who do you say? Jesus Christ in Latin American theology. Maryknoll, NY: Orbis.

Cady, S, Ronan, M \& Taussig, H 1986. Sophia: The future of feminist spirituality. San Francisco, CA: Harper \& Row.

Caprio, B 1982. The woman sealed in the tower: A psychological approach to feminine spirituality. New York/Ramsey: Paulist.

Croatto, J S 1989. Spiritual formation and critical study, in Amirthan \& Pryor 1989.

Cousins, E H 1990. What is Christian spirituality?, in Hanson, B C, 39-51.

De Villiers, P G R 1986. Use of Scripture and modern society: Political interpretations of the Bible. Inaugural lecture. Pretoria: University of South Africa.

- 1987. Liberation theology and the Bible. Pretoria: University of South Africa.

- 1993. Contextual theologies in the Bible and the struggle (for power). Scriptura, 128.

DiDomizio, D G 1981. Spirituality and politics: Seventeenth Century France, in Fox, M (ed), Western spirituality: Historical routes, ecumenical roots, 296-313. Santa $\mathrm{Fe}, \mathrm{CA}$ : Bear.

Eire, C M N 1990. Major problems in the definition of spirituality as an academic discipline, in Hanson, B C, Modern Christian spirituality.

Fabella, V, Lee, P K H \& Kwang-sun Suh, D (eds) 1992. Asian Christian spirituality: Reclaiming traditions. New York: Orbis.

Forde, G O 1984. When the old gods fail: Martin Luther's critique of mysticism, in Lindeberg, C (ed), Piety, politics and ethics: Reformation studies in honor of George Wolfgang Forell, Kirksville: The Sixteenth Century Journal Publishers. (Sixteenth Century Essays \& Studies 3.)

Fox, M (ed) 1981. Western spirituality: Historical routes, ecumenical routes. Santa Fe, CA: Bear. 
Galilea, S 1988. The way of the living faith. London: Collins.

Groeschel, B J 1988. Spiritual passages: The psychology of spiritual developments. New York: Crossroad.

Hall, T H 1990. The shape of Reformed piety, in Maas \& O'Donnell 1990.

Hambrick-Stowe, C E 1990. Loss and hope in Reformed spirituality: The example of Anne Bradstreet, in Hanson 1990: 85-112.

Hanson, B C 1982. Christian spirituality and spiritual theology. Dialog 21, 207-212.

Hanson, B C 1990. Modern Christian spirituality: Methodological and historical essay's. Atlanta: Scholars Press.

Harkness, G 1973. Mysticism: Its meaning and message. Nashville: Abingdon.

Jeffrey, D L 1987. A burning and a shining light: English spirituality in the age of Wesley. Grand Rapids: Eerdmans.

Jantzen, G M 1995. Power, gender and Christian mysticism. Cambridge: Cambridge University Press. (Cambridge Studies in Ideology and Religion.)

Leech, K 1977. Soul friend: A study of spirituality. London: Sheldon Press.

Lindeberg, C (ed) 1984. Piety, politics and ethics: Reformation studies in honor of George Wolfgang Forell. Kirksville: The Sixteenth Century Journal Publishers. (Sixteenth Century Essays \& Studies 3.)

Lovelace, R 1973. The sanctification gap. Theology Today 29, 365-366.

Maas, R \& O'Donnell, G 1990. Spiritual traditions for the contemporary church. Nashville, TN: Abingdon.

McGinn, B, Meyendorff, J \& Leclerq, J 1988. Christian spirituality: Origins to the twelfth century. New York: Crossroad. (World Spirituality: An Encyclopedic History of the Religious Quest 16.)

McGovern, A F 1989. Liberation theology and its critics: Toward an assessment. Maryknoll, NY: Orbis.

McGrath, A E 1994. Spirituality in an age of change: Rediscovering the spirit of the Reformers. Grand Rapids, MI: Zondervan.

McGovern, A F 1989. Liberation theology and its critics: Toward an assessment. Maryknoll, NY: Orbis.

Merton, T 1961. Seeds of contemplation. Wheathampstead: Anthony Clarke Books. 
Min, A K 1989. Dialectic of salvation: Issues in theology of liberation. Albany: State University of New York.

Minke, Sr 1989. Spiritual formation and liturgical life: A case study, in Amirtham \& Pryor, 1989:31-36.

Pryor, R 1989. Other resources on spiritual formation, in Amirtham \& Pryor 1989:100122.

Rayan, S 1992. The search for an Asian spirituality of liberation, in Fabella, Lee \& Kwang-sun Suh, 1992:11-30.

Romano, C A 1981. A psycho-spiritual history of Teresa of Avila: A woman's perspective, in Fox 1989.

Roten, J G 1994. The Marian counterpoint of postmodern spirituality, in Astell 1994.

Ruether, R R 1981. Patristic spirituality and the experience of women in the Early Church, in Fox 1989:140-163.

Schmiel, M A 1981. The finest music in the world: Exploring Celtic spiritual legacies, in Fox 1989:164-192.

Schneiders, S M 1989. Scripture and spirituality. Christian Spirituality 1, 1-20.

- 1990. Spirituality in the academy, in Hanson 1990:15-37.

Schottroff, L 1983. Women as followers of Jesus in New Testament times; an exercise in social-historical exegesis of the Bible in Gottwald N K (ed). The Bible and Liberation. Political and social hermeneutics. Maryknoll: Orbis.

Schüssler Fiorenza, E 1983. You are not to be called father: Early Christian history in a feminist perspective, in Gottwald, N K, The Bible and liberation, political and social hermeneutics. Maryknoll, NY: Orbis.

Senn, F C 1986. Lutheran spirituality, in Senn, F C (ed), Protestant spiritual traditions, 9-54. New York:Paulist.

Smit, D J 1989a. Kan spiritualiteit beskryf word? NGTT 30, 83-94.

- 1989b. Wat is Gereformeerde spiritualiteit? NGTT 30, 182-193.

Sobrino, J 1984. The true church and the poor. London: SCM.

- 1985. Spirituality of liberation: Toward political liberation. Maryknoll, NY: Orbis. (Theological Forum, GES April 1987.) 
Van Harskamp, A 1997. Religie in een tijd van individualisering. TvT 37, 243-264.

Whitehead, M 1991. Luce Irigaray: Philosophy in the feminine. London: Routledge.

Wright, W W 1990. Jane de Chantal's guidance of women: The Community of the Visitation and womanly values, in Hanson 1990:113-138. 